\title{
Study of the impact of contemporary architecture on Islamic motifs (or geometric patterns) in mosques
}

\author{
Mehdi Niknam, \\ Ph.D. in Architecture, Young Researchers Club, Islamic Azad University, Tabriz, Iran. \\ Mehdinikc@gmail.com \\ Sina Rezaei \\ Bachelor of Architecture, Shahid Beheshti Technical and Vocational School, Karaj, Iran \\ Sinarezaee64@gmail.com \\ Mohammad Hassan Zehtaban \\ Bachelor of Architecture, Shahid Beheshti Technical and Vocational School, Karaj, Iran \\ mh.zehtaban@gmail.com
}

\begin{abstract}
One necessary point in constructing biological life of people is the existence of common roots among a certain class of people. In one hand, these common roots such as beliefs are equal in one part of the world, so it conducts architecture's developing path through the same way in that part of the world, and on the other hand, it fills all concepts of architecture with value significance. Perhaps it is due to this point of view which considersarchitecture of each part of the world as an identity for that part. In the modern era especially in the field of ideas' interaction, the process of globalization needs to apply some elements in biological society which play adominant role in people's beliefs, and what will be more desirable than architectural signs in environment which are directly judged by all people. The architecture of mosques is regarded as the most prominent proof of architecture derivedfrom Islamic art and instructions which can be the turning point of architecture's evolution in the field of Islamic art. In the present research, we have tried to study the instances of mosques' architecture in Iran and contemporary world based on analyzing intellectuals' perspectives toward Islamic art. Through this research, It is expected for researchers to tangibly comprehend the process of evolution in mosques and Islamic centers' architecture as the most fundamental sign of Islamic art in world and in the modern era, and to clarify that in comparison to various interests of world's designers and architects, which patterns of Islamic art hidden in these signs are more stable.
\end{abstract}

Key words: Islamic art, traditional architecture, contemporary architecture, mosque.

\section{Introduciton}

Each piece of art can last for a long time when the creator uses deep and strong rules to create it. Due to close relationship with art, architectural works are not exceptional. If the rules used in architectural works of each part of the world are derived from ordinary people's beliefs, they will have more desirable results in improving the architecture of that section. Muslim artists and architects through using Islamic concepts have created outstanding works whose value and stability have grown up through the passage of time. This value and stability is all due to using Islamic instructions in providing architectural works. Because thedomeisdrawntowardthe sky, the treeof heaven(Tuba) wasthe most appropriatemotifsto decorateits inner surface. Aprime examplecan be seenintheDome of the Rockanditsfulluniversaltreethatgrowsfroman Islamic perspectivefrom top to bottom" (Azhand, 2009:34). In the field of studying the process of evolution in Islamic architecture, several analysis have been done by eastern and western philosophers and researchers in which all of these analysis concluded an undeniable reality and that is deep and rich concepts hidden in Islamic instructions in the field of architecture. "reluctancytoiconographyin Islam, has two aspects: on one hand it guaranteesandconfirmsthe greatness ofman's eternal, and on the other hand, nothing even a thing which partially or temporarily turns to an obstacle, should not separate man and the invisible presence of god" (Ahmadi Shalmani, 2011:83). Regarding the mentioned matter, it seems that in the evolution of cultures and interests of designers especially in designing Islamic religious centers, mosques of which are the significant samples of Islamic architecture, there are various patterns which have preserved their deep concepts and stability in contrast to interests of world other designers. Regarding this point, we have tried to do a research for achieving a small part of such stable art and Islamic architecture patterns through studying instances of architecture of mosques in all over the world. Recognizing such concepts and patterns can certainly help thedynamicprocess ofgrowth and developmentof Islamic architecture. 


\section{Mosque architecture}

The identity of Iranian architecture such as environmental, religious, instructional identity and symbolic patterns have created different forms in the historical process of architectural works. In reviewing past, in the first Hijri centuries, Muslim architects explored pre-Islamicarchitectural patterns, and if they were consistent with ideas, environmental and religious identity, they would be used and recreated depending on circumstancesof time and place in each historical period. Meanwhile mosque architecture was a priority. Mosque Islamic architecture sketches the skill of Muslim artists and artistic elements and images which possess various spiritual dimensions (Pour Jafar, 2011). Concerning the man as an important viewer of past architectural works, dense urbancontextand interwovenin the central plateauof Iran,domes,balconies,minarets, Viewscovered withcolored lines, writteninscription withspatialorganization of thecentral space counted as the spatial features of mosquearchitecture in Islamic period.Muslim architect follows Iranian architecture in Islamic era which was based on principles taken from religious beliefs, image shaping and religious instructions, and pictorial forms taken from environmental, instructional and religious identities have been always taken into consideration. The firstmosquein the Islamic world was designed bythe Prophetin Medinawitha chamberpattern usingthetrunks and branches oftrees, and built with the help ofcompanions. Since the place chosen to be a worshiping place in every time or every religion can change through the change in culture and it can receive those changes in accordance with the new religion and continues its material and spiritual life and holiness (Kaboli, 1997). As an instance in Iran, the Zoroastrian temple was considered as the pattern of the first mosques following formal changes in the first centuries after Islam and chamber pattern gradually is integrated with central spatial organization before Islam, and the mosques are designed with the pattern of central yard and chamber, while religious beliefs were matching the pattern of central yard. Images and symbols used before Islam and taken from religious identity survive even in post-Islamic works in accordance with religious beliefs, and these religious beliefs or other arts related to architecture such as sculpture have attracted the attention of Muslim architect to a religious identity and we can more or less observe its manifestation in post-Islamic geometric designs. Since the context, significance, aim and the process of idea to form is rooted in religious architecture, then this idea is in the form of a mosque originally taken from the architecture of Medina mosque. No message or Visualexpression can be independent on its particular time conditions or its environmental situations. Time is one of the most important factors which make the architect recognize the identity and symbols manifested in his work (Iranmanesh, 1997). This attitude doesn't confirm using current materials for recreating past forms, because the natural features of each material and its technical structure would show the method of using that material in architectural elements and recreating last factors with the old forms as the symbol of collective memory with the current materials as a hidden structure is considered as an inappropriate solution.

\section{3. physical- content concepts of mosque architectures}

In the first century $\mathrm{AH}$, the main parts of a mosque consists of vast space, Mihrab, Minbar and ordinary yards decorated with beautiful space creation. Following developments in prophet period in Medina or next centuries, these parts were necessary criterions for Muslims' worshiping place. At that time, there was no stable form for any of the part, however, there was a special design allocated to some parts such as Mihrab or Minbar. There was an apparent order in internal space similar to chamber form where there were located many vertical columns with monotonous decoration under the roof, and as the time passed, other basic parts also were formed in the completed structure of mosque architecture (Gerabar, 1997).Central organization followed with big yards having one, two or four porches and one central dome are considered as the basic changes of mosque's primitive pattern in Iranian architecture. Many architectural features such as dome and minaret in mosque building are related to next centuries which added identity to the spatial pattern and organization of primitive mosques. The symbols of decoration had different images in different periods. Mosques' decoration in Safavid period's social system started to flourish and then it was descended to a lower level in Qajar era and they find a simple symbol in the scale of town and city. 


\section{The conceptual origin ofmosque's physical elements}

The construction of mosque from the first patterns till now, were followed with basic physical elements appeared in different time and place conditions based on original conceptual structure.InPhenomenologicalstudyof these elements, wecanpointtothe followingconcepts:

Table No. 1-the conceptual origin of mosque's physical elements

\begin{tabular}{|c|c|}
\hline $\begin{array}{l}\text { Physical } \\
\text { element }\end{array}$ & The conceptual origin \\
\hline $\begin{array}{l}\text { Entrance } \\
\text { porch }\end{array}$ & $\begin{array}{l}\text { Calling and inviting Doorwaywithvisualimprintingandcolors in } \\
\text { loftystructural,urbantransformationandconstruction of the mosque, the space of presence, } \\
\text { passing, pause, connecting theurban scaletoarchitecturalscale, thelocation and its impression } \\
\text { symbolically shows the way of communicating mosquewithpeople. }\end{array}$ \\
\hline Inscription & $\begin{array}{l}\text { Writtenexpression ofdivineversesin the form ofcoloredmotifs, direct contact } \\
\text { withtheworshipersemphasizing divine instructions }\end{array}$ \\
\hline Porches & $\begin{array}{l}\text { Pauseandvisualgravity, } \\
\text { Archdifferentinshapeandbeing in theaxis of symmetryof the patio, the patioandthe } \\
\text { inneryardrelationship, formal narration ofmeaninghiddenin the background }\end{array}$ \\
\hline Dome & $\begin{array}{l}\text { Originofstructural form rooted inidentity of pre-Islamic Iranianarchitecture. AfterIslam the } \\
\text { symbol and polishing done with lots of decoration;from the internal perspective,visual and } \\
\text { conceptualtranscendentto the sky from external perspective, a sign ofvisualgloryof Muslims' } \\
\text { worshiping place }\end{array}$ \\
\hline Mihrab & $\begin{array}{l}\text { On one hand focusing onindividual, directionanddivineturnand on the other hand, } \\
\text { transcendentaldirectionand } \\
\text { sinkingandcentralizing }\end{array}$ \\
\hline stem & $\begin{array}{l}\text { Domeseenfrom human sight, raising the dome, the location of inscriptionsanddecoration, a } \\
\text { place for light shining }\end{array}$ \\
\hline Yard & Worshiping place, praying, prayers' deliberation \\
\hline Minaret & In the past release of call to prayer to the far places, today symbolism \\
\hline patio & $\begin{array}{l}\text { A big yard, enclosed space withoutcoverage, based on the identityofthe } \\
\text { architecturalenvironment, play a decisive rolein the hierarchy ofoutdoor, semi-open and closed }\end{array}$ \\
\hline
\end{tabular}

(Source: Pour Jafar, 2011)

\section{The analysis of instances from modern architecture of Iran and world mosques}

In this part, we have tried to present some remarkable features of world mosques:

5-1- the evolution of mosque architecture using East Asia style (china)

Why there is the title Chinese style in mosque architecture in asia is because all changes in east Asia mosque architecture is mostly done in china, and the main changes are as follows:

-rotation of main axis (construction) and the big entrance door of yard for prayers

-minarets, moon sighting chambers, dome and Mihrab 
Table No.2- instances form east Asia mosque architecture

\begin{tabular}{|c|c|c|c|c|}
\hline No. & $\begin{array}{l}\text { The work and } \\
\text { the name of } \\
\text { the architect }\end{array}$ & location & Remarkable features of the work & sample \\
\hline 1 & $\begin{array}{l}\text { Quran Islamic } \\
\text { academy, } \\
\text { designer: } \\
\text { Dong Ri Zhao }\end{array}$ & $\begin{array}{l}\text { Beijing, } \\
\text { china, } \\
1957\end{array}$ & $\begin{array}{l}\text { 1- Four floors suitable with usage } 2 \text {. } \\
\text { Theplacementofworship(mosque) on the first } \\
\text { floor } \\
\text { 3.threedomesas a symbol ofIslamic } \\
\text { architectureinwork }\end{array}$ & in \\
\hline 2 & $\begin{array}{l}\text { Kao Lun } \\
\text { mosque } \\
\text { designer: } \\
\text { A.M. Kardy }\end{array}$ & $\begin{array}{l}\text { Hong } \\
\text { Kong } 1984\end{array}$ & $\begin{array}{l}\text { 1-the main yard located in ground floor } \\
\text { 2-smaller yard located in upper floor for } \\
\text { ladies } \\
\text { 3-the main dome and four minarets covered } \\
\text { with marble }\end{array}$ & \\
\hline 3 & $\begin{array}{l}\text { Abu Bakr Al- } \\
\text { Sedigh } \\
\text { mosque } \\
\text { designer: } \\
\text { Abdol Majid } \\
\text { Hajidar }\end{array}$ & $\begin{array}{l}\text { Kuala } \\
\text { Lumpur, } \\
1982\end{array}$ & $\begin{array}{l}\text { 1-Atriangularsite } \\
\text { 2-Theheight of square-like central lobby } \\
\text { equals threefloors } \\
\text { 3-very } \\
\text { largeopeningswithoutcolumnsimplemented } \\
\text { inthelobby 4-a golden dome followed with a } \\
\text { single minaret }\end{array}$ & \\
\hline 4 & $\begin{array}{l}\text { Brunei Dar-o- } \\
\text { Salam School } \\
\text { mosque } \\
\text { designer: } \\
\text { Edris }\end{array}$ & $\begin{array}{l}\text { Begawan, } \\
\text { Brunei, } \\
1995\end{array}$ & $\begin{array}{l}\text { 1-Covered withtilesderived } \\
\text { fromIslamicDome } \\
\text { 2- Theminaretsarea symbol ofarchitecture of } \\
\text { Islamic mosques } \\
\text { 3-a separateyardfor men andwomen }\end{array}$ & \\
\hline 5 & $\begin{array}{l}\text { Islamic center } \\
\text { and Al-Azam } \\
\text { mosque } \\
\text { designer: } \\
\text { Abdol Majid } \\
\text { Hajidar }\end{array}$ & $\begin{array}{l}\text { Malé, } \\
\text { Maldives, } \\
1984\end{array}$ & $\begin{array}{l}\text { 1-The existence of dome and minaret in the } \\
\text { work } \\
\text { 2-the easy access of main mosque form } \\
\text { outside } \\
3 \text {-using white as the dominant color and } \\
\text { arches }\end{array}$ & \\
\hline 6 & $\begin{array}{l}\text { Singapore } \\
\text { mosque } \\
\text { designer : the } \\
\text { special board } \\
\text { of } \\
\text { construction } \\
\text { and } \\
\text { development }\end{array}$ & $\begin{array}{c}\text { Singapore } \\
1977\end{array}$ & $\begin{array}{l}\text { 1-internal design } \\
\text { 2-a central skylight derived fromIslamic } \\
\text { domes } \\
\text { 3-minaret and a red onion-like dome }\end{array}$ & \\
\hline
\end{tabular}

(Source: authors) 
Table No.3- instances form east Asia mosque architecture

\begin{tabular}{|c|c|c|c|c|}
\hline No. & $\begin{array}{l}\text { The work and } \\
\text { the name of the } \\
\text { architect }\end{array}$ & Location & Remarkable features of the work & sample \\
\hline 1 & $\begin{array}{l}\text { Fooladshahr } \\
\text { Mosque } \\
\text { designers: } \\
\text { Mohammad Ali } \\
\text { Badri Zade, Hadi } \\
\text { Mirmiran }\end{array}$ & $\begin{array}{l}\text { Iran, Isfahan, } \\
\text { Fooladshahr, } \\
1972 \text { Hijri }\end{array}$ & $\begin{array}{l}\text { 1-various views in outside layers } \\
\text {-using titled roof for light entry } \\
\text { 3-using modern materials such as } \\
\text { concrete } \\
\text { 4-minaret or the place of prayer } \\
\text { calling is implemented in a different } \\
\text { form }\end{array}$ & \\
\hline 2 & $\begin{array}{l}\text { Shah Khaled } \\
\text { airport mosque, } \\
\text { HellmuthT Obata } \\
\text { and } \\
\text { Kassabaum }\end{array}$ & Riyadh, 1983 & $\begin{array}{l}\text { 1-The major use ofthe geometry } \\
\text { especiallyequilateral triangle } \\
\text { 2-using concrete and steel for } \\
\text { building mosque dome } \\
\text { 3-the form of mosque is a hexagonal } \\
\text { plan }\end{array}$ & \\
\hline 3 & $\begin{array}{c}\text { Shah Feisal } \\
\text { mosque, designer: } \\
\text { Abdol Vahid al- } \\
\text { Vakil }\end{array}$ & $\begin{array}{l}\text { Islamabad, } \\
\text { Pakistan, } \\
1988\end{array}$ & 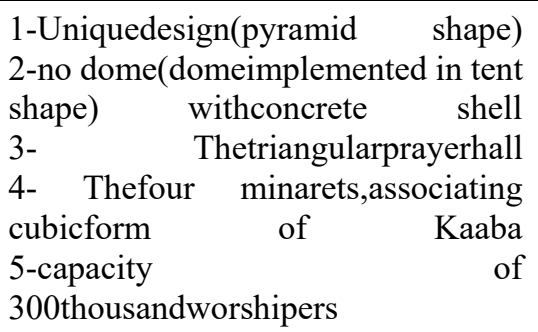 & \\
\hline 4 & $\begin{array}{c}\text { Dadamyan } \\
\text { mosque designer: } \\
\text { Hiren Patel }\end{array}$ & $\begin{array}{l}\text { Ahmadabad, } \\
\text { Hindustan, } \\
2002\end{array}$ & $\begin{array}{l}\text { 1-designing in residential district } \\
\text { with high density } \\
\text { 2-concrete modern materials } \\
\text { 3-presenting a rough texture covered } \\
\text { with concrete, no tangible minaret }\end{array}$ & \\
\hline 5 & $\begin{array}{c}\text { Al Qubaib } \\
\text { BED Engineering } \\
\text { company plan }\end{array}$ & $\begin{array}{c}\text { Doha, Qatar } \\
1998\end{array}$ & $\begin{array}{l}\text { 1-withspecialdomein the Persian } \\
\text { Gulf } \\
\text { 2.Replacement ofoldmosque } \\
\text { 3. Theshell is similar to the old } \\
\text { buildingwithmodern } \\
\text { facilitieslikeindoors }\end{array}$ & \\
\hline 6 & $\begin{array}{l}\text { West Bank } \\
\text { mosque, Halku } \\
\text { Department of } \\
\text { Architecture }\end{array}$ & $\begin{array}{c}\text { Amman, } \\
\text { Jordan, } 1980\end{array}$ & $\begin{array}{l}\text { 1- alargecentral dome } \\
\text { 2- Themain structure of the mosque } \\
\text { concrete-framed } \\
\text { 3- Thedome with concrete shell } \\
\text { 4- Theform of the work evokes a } \\
\text { shape of aship } \\
\text { 5-There are concretefountains } \\
\text { andelements }\end{array}$ & \\
\hline
\end{tabular}

(Source: authors) 
Table No. 4- instances from architecture of Europe mosques

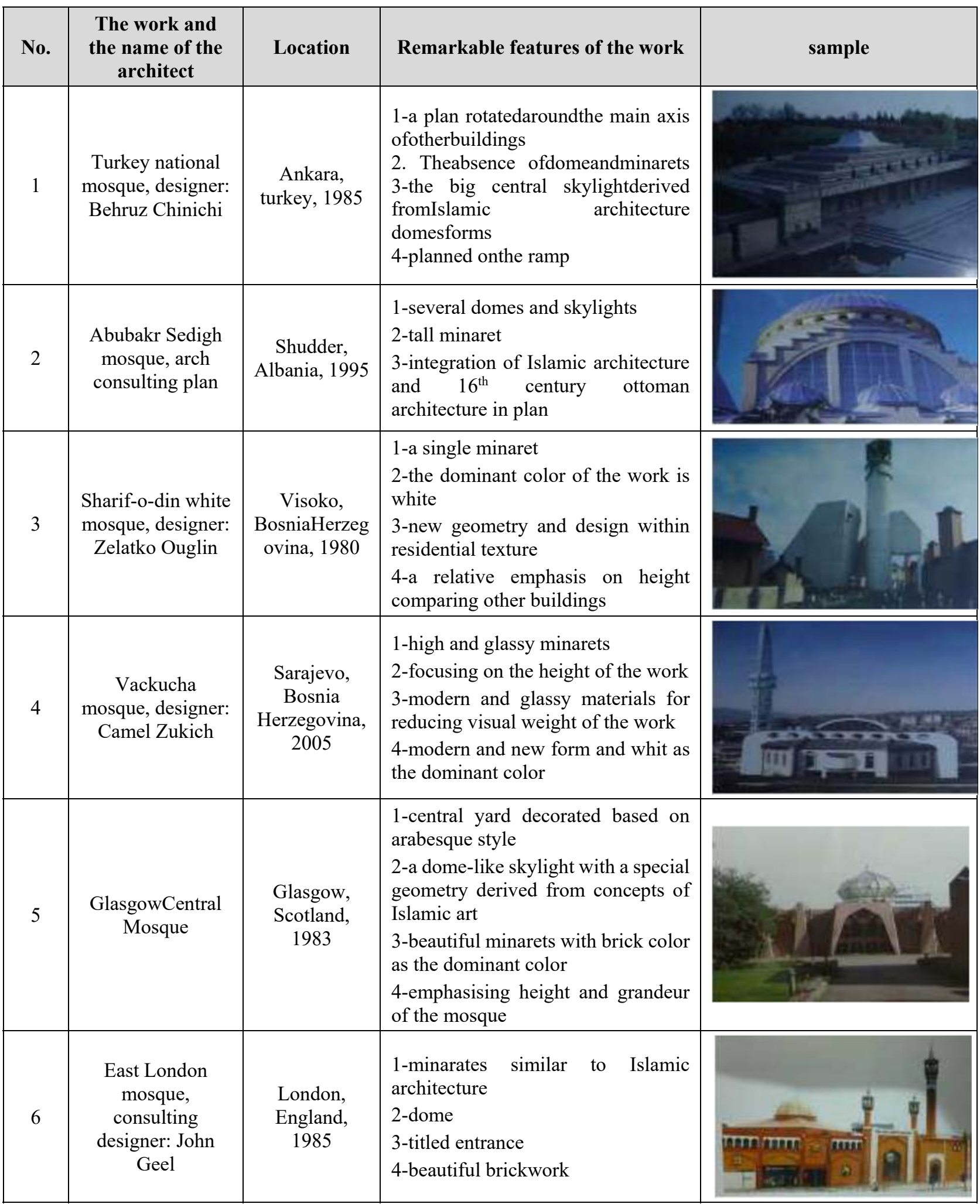

(Source: authors) 
Table No.5- instances form architecture of America's mosques

\begin{tabular}{|c|c|c|c|c|c|}
\hline No. & $\begin{array}{l}\text { The work and } \\
\text { the name of the } \\
\text { architect }\end{array}$ & Location & Remarkable features of the work & sample & \\
\hline 1 & $\begin{array}{c}\text { New YorkIslamic } \\
\text { center, designer: } \\
\text { SAM }\end{array}$ & $\begin{array}{l}\text { Network, } \\
\text { America, } \\
1991\end{array}$ & $\begin{array}{l}\text { 1-the central big dome } \\
\text { 2-using height and grandeur in great } \\
\text { amount } \\
\text { 3-using arabesque designs and } \\
\text { frames with new materials }\end{array}$ & & \\
\hline 2 & $\begin{array}{l}\text { Beit-o-Salam, } \\
\text { designer: Nasir } \\
\text { Ahmad }\end{array}$ & $\begin{array}{c}\text { Toronto, } \\
\text { Canada, } 1992\end{array}$ & $\begin{array}{l}\text { 1-using dome and minaret in the } \\
\text { work } \\
\text { 2-using white as the dominant color } \\
\text { 3-the dignity of the construction } \\
\text { 4-the special geometry used in } \\
\text { minaret of the work }\end{array}$ & & \\
\hline 3 & $\begin{array}{c}\text { Venezuela } \\
\text { mosque, } \\
\text { designers: Oscar } \\
\text { Brachu, Zoha } \\
\text { Fayaz }\end{array}$ & $\begin{array}{c}\text { Caracas, } \\
\text { Venezuela, } \\
1993\end{array}$ & $\begin{array}{l}\text { 1-dome and minaret } \\
\text { 2-emphasising height } \\
\text { 3-integration of modern and } \\
\text { Islamicarchitecture } \\
\text { 4-inviting using a platform } \\
\text { extending form street to dome }\end{array}$ & & \\
\hline 4 & $\begin{array}{c}\text { Coco Yembu } \\
\text { mosque }\end{array}$ & $\begin{array}{l}\text { Myakka, } \\
\text { Colombia, } \\
2007\end{array}$ & $\begin{array}{l}\text { 1-using the concepts of mosques' } \\
\text { Islamicarchitecture } \\
\text { 2-islamic arches } \\
\text { 3-combination of red as the } \\
\text { favorable color }\end{array}$ & & \\
\hline 5 & Bob-o-Aleslam & $\begin{array}{c}\text { Tacna, Peru, } \\
2008\end{array}$ & $\begin{array}{l}\text { 1- using the concepts of mosques' } \\
\text { Islamicarchitecture } \\
\text { 2-nice white minarets and domes } \\
\text { 3-creating beautiful porches suiting } \\
\text { area climate } \\
\text { 4-a sample implemented by Islamic } \\
\text { architecture in LatinAmerica }\end{array}$ & & 7 \\
\hline
\end{tabular}

(Source: authors)

6. How the intellectual basic principles of traditional mosques are shown in modern structures?

The principles which are available in traditional mosques and can be applied in modern structures are generally as follows;

- An attempt to achieve monotheism

- The main direction toward monotheism and God

- Unity in meaning and body

- Considering background

- An attempt to achieve perfection

-Order and symmetryandharmony in thebody, meaning and function

-Justiceand balance in thewhole and the part

- Considering the blessingsand utilizationofnatural factorsandnaturaland Islamic motifs

-Lack ofindividualityand anonymity in work

-Constructionas an act with adevotionalapproach 


\section{Conclusion}

Religious places designed based on religion in every part of the world are always in priority due to the close relationship with deep beliefs and concepts accepted by all people. Accordingly the researchers emphasize that in order to introduce and recognize the culture of each nation, we must refer to architectural works of that nation. So regardless of all discussions around architecture's traditional works, it is needed for researchers to pay more attention to cultural items and the concepts hidden in these works especially religious works. If the stable concepts and patterns of religious constructions are correctly used and recognized, then two important goals can be achieved, the first one the architectural evolution process of each area will not lose its original way taken from deep thoughts, and second it can be provided to desirably integrate new technologies with traditional patterns to create new constructions and repair traditional works. In the present research we have tried to discuss a small part of concepts and principles of Islamic art and architecture which can be an opening way for researchers who are interested in Iran's Islamic culture and art.

\section{References}

[1] Iranmanesh, Mohammad, 1997, Fundamental Criticism of Attitudes toward Mosque Architecture, the Set of Articles for Mosque Architecture: Past, Present, Future.

[2] Bani Masood, Amir, 2011, Iran Contemporary Architecture, Architecture Art of Century Publication, Tehran

[3] Pour Jafar, Mohammad Reza et al, 2011, The Architecture of Modern and Contemporary Mosques, Tahan Publication.

[4] Dolat Abadi, Yahya, 1982, Hayat Yahya, Firdausi Publication, Tehran, vol. 4.

[5] Kaboli, Mir Abedin, 1997, Reincarnation and Holiness inReligious Architecture, the Set of Articles for Mosque Architecture: Past, Present, Future.

[6] Gerabar, Alag, 1997, Ttranslator: Najafi Barzegar, Hussein, Mosque in Islamic Contemporary Societies, Architecture and Art Magazine of "Art", No. 33.

[7] Marefat, Mina, 1996, PioneersWhoFormedtheModernTehran, Tehran Technical and Engineering Consulting Organization.

[8] Nabavi, Negin, 2001, Intellectuals and the Talk over Iran Folk Culture, Iranian Magazine Letter 3.

[9] Noghre Kar, Abdol Hamid, 1997, Mosque Architecture from Concept to Body, the Set of Articles for Mosque Architecture, Past, Present, Future.

[10] Soleymani, Mohammad Javad, 2000, Mosque Architecture, The Set of Articles for Mosque Architecture, Past, Present, Future, Isfahan, Art University.

[11] 11.Hashem Nezhad, Hussein, 2006, An introduction to the Philosophy of Art from Islamic Great Philosophers' points of view, Ghabsat Scientific Magazine, No. 39, Year 11.

[12] Bemanian, Mohammad Reza, 2010, ReadingSpiritual IdentityandSacred Characters in Architecture ofShiite Mosques, Publicationof theShia Studies, No. 30 